\title{
PROPOSAL PENAWARAN JASA PEMBUATAN WEBSITE

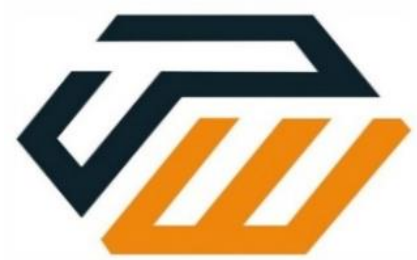

\section{TEKNOWEB}

(Disusun untuk memenuhi tugas mata kuliah Sistem Informasi Manajemen)

Dosen Pengampu :

Dr. Yahfizham, S. T., M.Cs

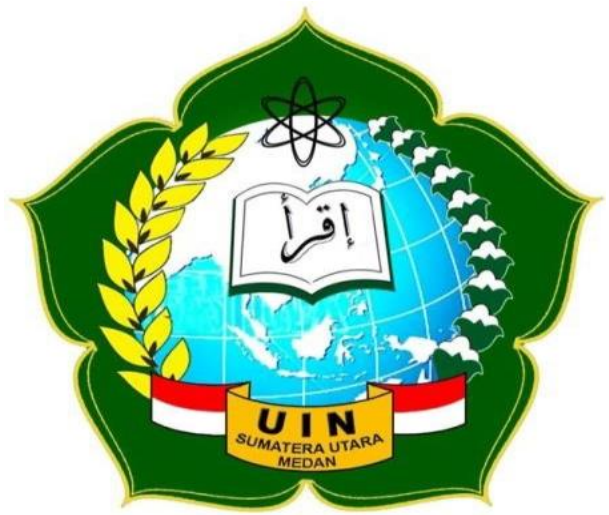

Disusun Oleh :

Yusuf Abdul Aziz Gea (0702193202)

Kelas : Sistem Informasi-4

PRODI SISTEM INFORMASI

UNIVERSITAS ISLAM NEGERI SUMATERA UTARA

FAKULTAS SAINS DAN TEKNOLOGI MEDAN 


\begin{tabular}{|l|l|}
\hline & $\begin{array}{c}\text { Yusuf Abdul Aziz Gea } \\
\text { Phone / What's up : 082166455075 } \\
\text { Link URL : www.teknoweb.id }\end{array}$ \\
\hline$\square=0$
\end{tabular}

Lampiran : 1 (satu ) set Proposal

Perihal : Penawaran Pembuatan Website

Kepada Yth.

Bapak / Ibu Pimpinan Perusahaan

Di Tempat

Dengan Hormat,

Sebelumnya kami ucapkan banyak terima kasih kepada Bapak atau Ibu yang telah menerima dan meluangkan waktu untuk membaca proposal penawaran ini sehingga Bapak atau Ibu dapat mempertimbangkan dan memilih beberapa produk jasa yang kami tawarkan.

Kami dari Teknoweb Indonesia merupakan salah satu website developer yang mengutamakan layanan khusus dalam pengembangan website, Teknoweb lebih menitikberatkan dalam pelayanan jasa pembuatan, pengembangan, dan memaksimalkan website untuk meningkatkan pengunjung pada website sehingga diharapkan dapat meningkatkan minat pengunjung untuk membeli produk atau jasa yang Anda tawarkan sesuai harapan.

Melalui proposal penawaran ini, kami menawarkan perancangan website untuk perusahaan Anda yang sedang Anda pimpin, Adapun produk jasa perancangan website yang kami tawarkan yang telah terlampir dalam proposal ini.

Atas perhatian dan kerjasamanya, kami ucapkan terima kasih.

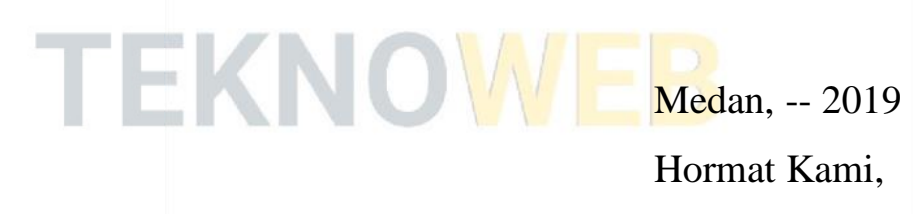




\section{Teknoweb Team}

\section{PENDAHULUAN}

Di zaman era globalisasi kemajuan teknologi informasi sangat berkembang pesat,informasi yang dapat kita ketahui dapat lebih mudah.tidak mengenal waktu dan tempat menjadi suatu hal yang sangat dibutuhkan oleh setiap orang yang semakin banyak menggunakan situs-situs web di internet sebagai wadah informasi secara global.website berguna untuk meningkatkan minat calon konsumen sehingga lebih mempercayai produk atau jasa yang ditawarkan terutama pada kalangan bisnis kecil hingga besar yang sudah banyak memanfaatkan website.produk dan jasa yang ditawarkan dalam meningkatkan minat calon konsumen sehingga lebih dipercaya.

website dapat menyajikan berbagai informasi mengenai profil perusahaan, profil lembaga, pendidikan, profil komunitas, kegiatan organisasi, serta media berbagai pengetahuan dan lain-lain. Website menjadi salah satu media yang dapatdiandalkan tidak hanya dapat digunakan oleh perusahaan atau lembaga besar saja,tetapi juga banyak digunakan di kalangan kecil serta menengah sebagai media promosi yang amat sekaligus menampilkan profesionalitas.

Dimana proses kerja perusahaan akan semakin terbantu dan lebih efektif dan efisien dan selain itu kebutuhan akan software dan program aplikasi berbasis web atau desktop sudah menjadi kebutuhan yang sangat penting bagi sebuah perusahaan. Sementara iklan di media massa, kosurat, sampai kartu nama usaha yang mencantumkan alamat web cenderung lebih berbobot dan lebih profesional. Dengan demikian perusahaan ataupun lembaga yang dimiliki situs web profesional dengan domain sendiri cenderung dianggap lebih bonafit.

Web desain yang dapat menawarkan Suatu bentuk kerjasama kepada bapak atau Ibu sebagai perusahaan Bersama ini kami Teknoweb Indonesia yang bergerak dalam bidang teknologi informasi.organisasi ataupun personal dalam memanfaatkan media internet sebagai pilihan bijaksana untuk mengembangkan potensi sekaligus sarana memperkenalkan (promosi) diri kepada seluruh Indonesia, dalam lembaga pendidikan, dan dalam lembaga pendidikan (formal/non formal). Serta dapat memenuhi target yang akan dirancang bersama anda,kami akan mencoba untuk membangun sebuah situs web yang sesuai dengan gambaran 
anda dan memiliki tujuan. Bagaimana sebuah situs web di tidak "mati" dan menarik untuk dikunjungi orang dari waktu ke waktu.

\section{MENGAPA WEBSITE ?}

Websiteadalah media promosi online berbentuk page/halaman di media internet yang khususnya menyediakan kapasitas yang sangat besar bagi perusahaan dalam menginformasikan data perusahaan seperti company profile, produk-produk, jasa-jasa dan masih banyak yang lainnya.website juga dapat memberikan solusi bagi dunia usaha guna menjangkau konsumen sebanyak-banyaknya dimana saja dan kapan saja, tidak terbatas wilayah geografis dan waktu.

perusahaan dapat menjelaskan produk/jasa andalan secara terperinci dan konsumen juga mendapatkan keterangan yang sangat terperinci secara cepat dan tepat kapan saja dan dimana saja Hal inilah yang akan menguntungkan perusahaan dan bagi konsumen.

\section{BEBERAPA ALASAN MENGAPA HARUS MEMPUNYAI WEBSITE}

- Denganmemiliki website maka produk kita akan lebih banyak dikenal masyarakat bahkan sampai depan mancanegara dan juga dapat memperluas jangkauan promosi

- Tanpa harus memiliki karyawan yang harus mempromosikan produk kita selama 24 jam sehari dan 7 hari seminggu dengan adanya website ini akan lebih menghemat tenaga / karyawan

- ide ataupun profil perusahaan kepada konsumen atau masyarakat umum sebagai media untuk memperkenalkan produk.

- jika dibandingkan dengan media promosi lainnya website ini merupakan media promosi yang sangat menawarkan biaya yang lebih murah (bahkan lebih muda dari dari biaya parkir) dan sangat efisien.

- website ini akan memberikan sebuah informasi yang lebih lengkap jelas mengenai profil perusahaan, produk dan layanan lainnya. 
- sehingga dapat menjalankan bisnis atau usaha walau di dari rumah sekalipun Anda bisa juga mempunyai website ini tanpa harus mempunyai kantor atau perusahaan.

- yang dapat menarik minat dan kepercayaan konsumen dengan desain yang profesional dan eksklusif

\section{JENIS PAKET DAN BIAYA LAYANAN}

\section{PAKET BASIC}

Paket Basic cocok digunakan untuk website yang tidak banyak menampilkan produk dan sebagai perkenalann website Anda kepada pengunjung seperti : profil perusahaan, layanan (perusahaan jasa) untuk memperkenalkan produk.

Rincian fasilitas dan biaya jenis paket ini meliputi :

\begin{tabular}{|c|c|c|c|}
\hline \multicolumn{4}{|c|}{$\begin{array}{l}\text { PAKET BASIC } \\
600.000 / \text { PER TAHUN }\end{array}$} \\
\hline LAYANAN & FITUR SERVER & FITUR EMAIL & FITUR UTAMA \\
\hline Desain Profesional & SSD Storage & POP3 / IMAP & Unlimited Email Account \\
\hline $500 \mathrm{Mb}$ Storage & Unlimited Bandwidth & SMTP & 500 MB Storage \\
\hline Domain (.com) & Web Accelerator & Auto Responder & Unlimited Bandwidth \\
\hline Free Maintenance & Website Builder & E-mail Forwarder & Unlimited Sub Domain \\
\hline Unlimited bandwith & Integerasi Google Apps & SpamAssassin Protection & Unlimited Addon Domain \\
\hline Support 24 jam & Unlimited Sub Domain & & 1 Email Account \\
\hline Gratis 1 banner & Unlimited Addon Domain & & 10 Sendmail / hour \\
\hline SSL Security & Unlimited Parked Domain & & 1 Database / Account \\
\hline Mobile friendly & Security Bit Ninja & & REE Web Builder \\
\hline SEO friendly & Garansi 30 Hari & & REE SSL Grade-A \\
\hline \multirow[t]{2}{*}{1 Email Addresses } & & & FREE Litespeed Web Cache \\
\hline & & & BIT NINJA SECURITY \\
\hline
\end{tabular}

- Menggunakan desain template sesuai dengan catalog kami

- Pelatihan untuk pengelolaan data website secara online / offline ( menyediakan kondisinya)

- Unlimited Halaman CMS WordPress (Costum) 
- Website Friendly

- Website SEO friendly

- Optimasi SEO Basic

- Fitur Chat \& Shert

- $\quad$ Support 24 Jam

- Jaminan Keamanan

- Google My Bussines \& Google Console

\section{PAKET PROFESIONAL}

Paket Profesional Cocok untuk Website Toko Online, Website Perusahaan, Portofolio

Rincian fasilitas dan biaya jenis paket ini meliputi :

\begin{tabular}{|c|c|c|c|}
\hline \multicolumn{4}{|c|}{$\begin{array}{c}\text { PAKET PROFESIONAL } \\
\text { Rp. 2.500.000 / PER TAHUN }\end{array}$} \\
\hline LAYANAN & FITUR SERVER & FITUR EMAIL & FITUR UTAMA \\
\hline Desain Profesional & SSD Storage & POP3 / IMAP & 1 GB Storage \\
\hline $1 \mathrm{~GB}$ Storage & Unlimited Bandwidth & SMTP & Unlimited Bandwidth \\
\hline Domain sesuai permintaan & Web Accelerator & Auto Responder & Unlimited Sub Domain \\
\hline Free Maintenance & Website Builder & E-mail Forwarder & Unlimited Addon Domain \\
\hline Unlimited bandwith & Integerasi Google Apps & SpamAssassin Protection & 2 Email Account / Up to \\
\hline Support 24 jam & Unlimited Sub Domain & & 25 Sendmail / hour \\
\hline Gratis 2 banner & Unlimited Addon Domain & & 10 Database \\
\hline SSL Security & Unlimited Parked Domain & & FREE Web Builder \\
\hline Mobile friendly & Security Bit Ninja & & FREE SSL Grade-A \\
\hline SEO friendly & Garansi 30 Hari & & FREE Litespeed Web Cache \\
\hline 2 Email Addresses & & & BIT NINJA SECURITY \\
\hline Premium Theme & & 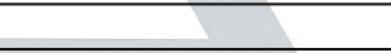 & Jeveloper Tools \\
\hline Free T-Shirt Ori & & & $\begin{array}{c}\text { (Ruby, Perl, Python, Git, SSH, } \\
\text { Composer) }\end{array}$ \\
\hline & & & SEO Assistant \\
\hline
\end{tabular}

- Menggunakan desain template sesuai dengan catalog kami

- Pelatihan untuk pengelolaan data website secara online / offline ( menyediakan kondisinya)

- Unlimited Halaman CMS WordPress (Costum)

- Website Friendly

- Website SEO friendlyOptimasi SEO Basic 
- Fitur Chat \& Shert

- $\quad$ Support 24 Jam

- Jaminan Keamanan

- Google My Bussines \& Google Console

\section{PAKET PLATINUM}

Paket Platinum cocok digunakan untuk Website Media Informasi, Website E-Commerce yang menampilkan produk dengan kualitas terbaik.

Rincian fasilitas dan biaya jenis paket ini meliputi :

\begin{tabular}{|c|c|c|c|}
\hline \multicolumn{4}{|c|}{ Rp. 4.900.000/ PER TAHUN } \\
\hline LAYANAN & FITUR SERVER & POP3 / IMAP & UNLIMITED Storage \\
\hline Desain Profesional, Semi Custom & NVME Storage & SMTP & Unlimited Bandwidth \\
\hline Unlimited Storage & Unlimited Bandwidth & Auto Responder & Unlimited Sub Domain \\
\hline Domain sesuai permintaan & Web Accelerator & E-mail Forwarder & nlimited Addon Domain \\
\hline Free Maintenance & Website Builder & Inlimited Email Account \\
\hline Unlimited bandwith & Integerasi Google Apps & SpamAssassin Protection & 50 Sendmail / hour \\
\hline Support 24 jam (Prioritas) & Unlimited Sub Domain & & 20 Database \\
\hline Gratis 4 banner & Unlimited Addon Domain & & FREE Web Builder \\
\hline SSL Security & Unlimited Parked Domain & & FREE SSL Grade-A \\
\hline Mobile friendly & Security Bit Ninja & & FREE Litespeed Web Cache \\
\hline SEO friendly & Garansi 30 Hari & & BIT NINJA SECURITY \\
\hline 4 Email Addresses & & & Developer Tools \\
\hline Premium Theme & & & (Ruby, Perl, Python, Git, SSH, \\
\hline Free T-Shirt Ori & & & Composer) \\
\hline & & & SEO Assistant \\
\hline
\end{tabular}

-. Menggunakan desain template sesuai dengan catalog kami

- Pelatihan untuk pengelolaan data website secara online / offline ( menyediakan kondisinya) 
- Unlimited Halaman CMS WordPress (Costum)

- Website Friendly

- Website SEO friendly

- Optimasi SEO Basic

- Fitur Chat \& Shert

- $\quad$ Support 24 Jam

- Jaminan Keamanan

- Google My Bussines \& Google Console

\section{PEMELIHARAAN DAN UPDATING WEBSITE}

Dalam pemeliharaan sangat bijaksana jika anda memasukkan perkiraan pengeluaran Untuk pemeliharaan situs website anda.pemeliharaan situs web termasuk pembaharuan data, perubahan skala kecil dan juga fine tuning.secara umum, jika situs web anda tidak diperbarui isinya selama kurang lebih 4 sampai 5 bulan,situs web Anda bisa menjadi layak anak yatim di dunia Internet, hal mana yang akan berpengaruh negatif bagi prestise lembaga/perusahaan anda.

terutama bila anda memutuskan bahwa situs web Anda adalah salah satu gerbang penting bagi masuknya pendapatan maupun Salah satu servis bagi perusahaan anda.situs web yang baik adalah situs web yang selalu menyajikan informasi terbaru dan akurat dan juga pemeliharaan berkala biasanya sangat dibutuhkan.kami akan menyediakan jasa pemeliharaan situs web, sehingga Anda tidak perlu repot melakukan updating lagi.

Sebagai informasi bahwa mesin pencari Google sangat kuat kepada website yangada pada menu berita/artikel yang selalu di-update, sehingga mudah terindex oleh Google dengan kata kunci tertentu. Melalui jasa pemeliharaan dan of dating pada website ini anda dapat menunjukkan kami berbagai pengelolaan website untuk mengupdate website milik anda setiap saat. Mengenai biaya jasa pemeliharaan dan of dating website silakan negosiasi kepada tim Teknoweb Indonesia.

\section{KESEPAKATAN LAYANAN}

Jika anda harus tetap menyetujui perjanjian ini selama anda menjadi Clan kami di Teknoweb Indonesia wajib membaca dan juga memahami syarat dan ketentuan sebelum memutuskan untuk menggunakan service Teknoweb Indonesia 
demi keamanan dan kelulusan pelanggan dalam menggunakan produk/jasa Teknoweb Indonesia dan dapat berbuah sewaktu-waktu sesuai kebutuhan. Perjanjian ini dibuat sedemikian rupa demi kepentingan bersama.

\section{SYARAT DAN KETENTUAN LAYANAN}

- Wajib memberikan nama lengkap dan jelas, alamat, alamat email yang valid dan informasi lain yang dibutuhkan serta asli.

- Nama domain hanya dapat satu kali dipilih dan tidak dapat diganti dengan domain lain.

- Akses hosting dan domain hanya dapat diakses oleh Team Teknoweb Indonesia demi keamanan script dan keleluasan client kami.

- Harga paket dan biaya perpanjangan sewaktu-waktu dapat berubah.

- Kami tidak bertanggung jawab atas isi materi dari website klien dan klien bertanggung jawab sepenuhnya atas materi didalam websitenya.

- Website tidak melanggar hukum dan UU (pornografi, aktivitas ilegal, dll), kami berhak menghentikan layanan atau menghapus layanan apabila pelanggaran dilakukan tanpa pemberitahuan.

- Masa kontrak layanan selama 1 tahun, Team Teknoweb Indonesia berhak menonaktifkan layanan apabila tidak ada perpanjangan masa kontrak layanan.

- Dengan memesan jasa pembuatan website di Teknoweb Indonesia, berarti klien setuju dengan Syarat dan Ketentuan Layanan diatas.

\section{PEMBUATAN WEBSITE}

- Proses baru akan kami mulai setelah menerima pembayaran, untuk transaksi DP 70\%

- Proses pembuatan di mulai setelah penyerahan bahan / materi dari klien seperti nama perusahaan perseorangan, logo, dll (sesuai kebutuhan).

- Desain Website dibuat sesuai pilihan dari klien dan sesuai paket yang dipilih klien.

- Revisi Desain Website hanya berlaku untuk Paket Custom.

- Kami memberikan garansi uang kembali apabila selama 1 minggu saat pengerjaan website tidak kami selesaikan (Tidak berlaku untuk paket custom).

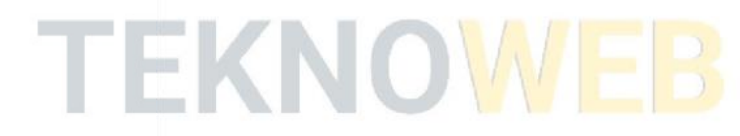




\section{Backup}

Backup dapat dilakukan sesuai paket yang dipilih klinko mas sebagai contoh paket basic dilakukan setiap bulan.back up adalah proses pembuatan data cadangan dengan cara menyalin atau membuat arsip semua data pada website sehingga apabila terjadi kerusakan pada server hosting Anda dapat melakukan proses restore atau pengembalian data yang sesuai tinggal backup terakhir.

\section{KLAIM UANG KEMBALI}

- Klaim uang kembali hanya untuk berlaku pada produk pembuatan website.

- Klaim hanya dapat dilakukan jika kami tidak menepati komitmen kami, yaitu menyelesaikan website Anda dalam waktu yang kami janjikan.

- Klaim tidak berlaku untuk alasan ketidakcocokan masalah desain dsbnya.

- Klaim tidak berlaku apabila data Anda terhapus, oleh karena itu kami menyediakan fasilitas backup sesuai paket yang dipilih klien.

- Pengembalian Uang Kembali, dilakukan 3 hari setelah klaim disetujui.

Demikian, Terms Of Services kami sampaikan sebagai satu informasi yang dapat dipahami kedua belah pihak.

\section{Frequently Asked Question}

- Bagaimana cara prosedur pemesanan Website?

Jika sudah deal Anda dapat melakukan pembayaran langsung ke kami dan untuk transaksi jasa pembuatan website Anda bisa membayar DP sebesar 70\% terlebih dahulu sehingga proses pembuatan website selesai.dan Anda harus bisa konsultasi terlebih dahulu ke kami tentang gambaran dan jenis website anda dengan menghubungi contact person kami.

- Berapa lama proses pembuatan website hingga dapat ditampilkan di Internet? Lama Untuk tema website yang kami sediakan lama proses pembuatan Max 4 hari,proses pembuatan tergantung dari tingkat kesulitan website. 
- Berapa biaya yang diperlukan untuk membangun website dari jasa Teknoweb Indonesia?

Biaya yang sudah termasuk domain dan hosting selama 1 tahun,merupakan biaya yang sudah tertera pada halaman proposal di atas.

- Berapa harga perpanjangan website setelah 1 tahun?

biaya perpanjang sewa sewaktu-waktu bisa berubah tanpa pemberitahuan sesuai ketentuan dari hosting dan domain dan jika biaya sewa Setelah 1 tahun tergantung jenis paket yang dipilih.

- Saya tidak mengerti sama sekali tentang pengeleloan website, apakah Team Teknoweb Indonesia akan membantu?

Kami akan membantu secara langsung kepada anda saat proses pengelolaan website Bagaimana cara mengelola website dengan tutorial mengelola website ini.

- Apakah saya bisa menambahkan fitur website sewaktu-waktu?

bisa, dengan melakukan perubahan fitur yang sesuai kebutuhan dan anda perlukan dan sesuai sumber daya yang dimiliki dan kami akan membantu dalam melakukan perubahan.

- Apakah Layanan ini bergaransi ?

untuk penjelasan lebih jelas boleh dibaca pada halaman ketentuan dan Rayan kami akan memberikan garansi dan juga layanan untuk pembuatan website apabila selama pengerjaan maksimal 7 hari ya aku akan launching di internet.

- Apa itu SEO ? Apakah penting untuk website yang saya kelola?

SEO atau Search Engine Optimization adalah suatu teknik untuk memaksimalkan suatu website agar lebih dikenal atau lebih mudah dibaca oleh search engine, tentu saja SEO sangat penting untuk mendatangkan lebih banyak pengunjung ke website Anda.

- Apakah Teknoweb Indonesia menyediakan jasa pemasangan artikel ? Betul, kami meyediakan jasa pengisian artikel bagi Anda yang sibuk, bingung, kesusahan untuk mengelola website Anda, untuk harga silahkan negosiasi dengan 
Terima kasih atas ketersediaan anda dan telah meluangkan waktu untuk membaca proposal kami, salam sukses. Tim Teknoweb Indonesia

\section{Kami Menerima Jasa Pembuatan Website :}

1. Company Profile (Perusahaan)

2. Online Shop (Toko Online / Marketplace)

3. Web Personal (Pribadi)

4. $\mathrm{B} \log$

5. News (Berita)

\section{PENUTUP}

Demikian proposal penawaran jasa pembuatan website ini Kami buat, dan Kami sangat senang jika Bapak / Ibu mau meluangkan waktu untuk berkonsultasi dengan Kami mengenai informasi pembuatan website ini. Detail info Klien Kami, silahkan kunjungi url berikut ini: www.teknoweb.id 